\title{
Front Matter: Volume 9226
}

, "Front Matter: Volume 9226," Proc. SPIE 9226, Nanophotonics and Macrophotonics for Space Environments VIII, 922601 (21 October 2014); doi: $10.1117 / 12.2086701$

SPIE Event: SPIE Optical Engineering + Applications, 2014, San Diego, California, SPIE. United States 


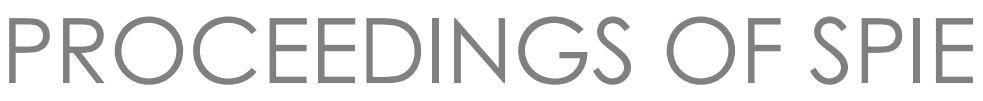

\title{
Nanophotonics and Macrophotonics for Space Environments VIII
}

\author{
Edward W. Taylor \\ David A. Cardimona
}

Editors

18-19 August 2014

San Diego, California, United States

Sponsored and Published by

SPIE 
The papers included in this volume were part of the technical conference cited on the cover and title page. Papers were selected and subject to review by the editors and conference program committee. Some conference presentations may not be available for publication. The papers published in these proceedings reflect the work and thoughts of the authors and are published herein as submitted. The publisher is not responsible for the validity of the information or for any outcomes resulting from reliance thereon.

Please use the following format to cite material from this book:

Author(s), "Title of Paper," in Nanophotonics and Macrophotonics for Space Environments VIII, edited by Edward W. Taylor, David A. Cardimona, Ronald G. Pirich, Narasimha S. Prasad, Proceedings of SPIE Vol. 9226 (SPIE, Bellingham, WA, 2014) Article CID Number.

ISSN: 0277-786X

ISBN: 9781628412536

Published by

SPIE

P.O. Box 10, Bellingham, Washington 98227-0010 USA

Telephone +1 3606763290 (Pacific Time) · Fax +1 3606471445

SPIE.org

Copyright (C) 2014, Society of Photo-Optical Instrumentation Engineers.

Copying of material in this book for internal or personal use, or for the internal or personal use of specific clients, beyond the fair use provisions granted by the U.S. Copyright Law is authorized by SPIE subject to payment of copying fees. The Transactional Reporting Service base fee for this volume is $\$ 18.00$ per article (or portion thereof), which should be paid directly to the Copyright Clearance Center (CCC), 222 Rosewood Drive, Danvers, MA 01923. Payment may also be made electronically through CCC Online at copyright.com. Other copying for republication, resale, advertising or promotion, or any form of systematic or multiple reproduction of any material in this book is prohibited except with permission in writing from the publisher. The CCC fee code is 0277-786X/14/\$18.00.

Printed in the United States of America.

Publication of record for individual papers is online in the SPIE Digital Library.

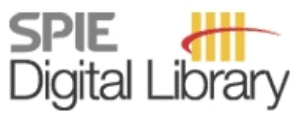

SPIEDigitalLibrary.org

Paper Numbering: Proceedings of SPIE follow an e-First publication model, with papers published first online and then in print and on CD-ROM. Papers are published as they are submitted and meet publication criteria. A unique, consistent, permanent citation identifier (CID) number is assigned to each article at the time of the first publication. Utilization of CIDs allows articles to be fully citable as soon as they are published online, and connects the same identifier to all online, print, and electronic versions of the publication. SPIE uses a six-digit CID article numbering system in which:

- The first four digits correspond to the SPIE volume number.

- The last two digits indicate publication order within the volume using a Base 36 numbering

system employing both numerals and letters. These two-number sets start with 00, 01, 02, 03, 04, $05,06,07,08,09,0 A, 0 B \ldots$. 0Z, followed by 10-1Z, 20-2Z, etc.

The CID Number appears on each page of the manuscript. The complete citation is used on the first page, and an abbreviated version on subsequent pages. Numbers in the index correspond to the last two digits of the six-digit CID Number. 


\title{
Contents
}

\author{
$\checkmark$ Authors \\ vii Conference Committee \\ ix Introduction
}

\section{KEYNOTE SESSION}

922602 Microfossils and biomolecules in carbonaceous meteorites: possibility of life in waterbearing asteroids and comets (Keynote Paper) [9226-9]

\section{SESSION 1 TECHNOLOGY FOR PLANETARY DEFENSE}

922603 Optical modeling for a laser phased-array directed energy system (Invited Paper) [9226-1]

922604 DE-STARLITE: A directed energy planetary defense mission [9226-2]

922605 Frequency stabilized lasers for space applications [9226-3]

922606 Directed energy active illumination for near-Earth object detection [9226-4]

922607 Effects of asteroid rotation on directed energy deflection [9226-5]

922608 Recent advances in laser ablation modelling for asteroid deflection methods (Invited Paper) [9226-6]

\section{SESSION 2 SPACE EXPERIMENTS, SYSTEMS, AND COMPONENTS}

922609 Post-flight test results of acousto-optic modulator devices subjected to space exposure (Invited Paper) [9226-7]

9226 OA System engineering of photonic systems for space application (Invited Paper) [9226-8]

SESSION 3 THEORETICAL AND SIMULATED TESTING OF ADVANCED PHOTONIC MATERIALS

9226 OB Sensitivity of rarefied gas simulations of ground tests to gas surface models (Invited Paper) [9226-10]

9226 0C Determining the molecular origin of radiation damage/enhancement in electro-optic polymeric materials through polarized light microscopy (Invited Paper) [9226-11] 


\section{SESSION 4 FIBER OPTIC TECHNOLOGY}

9226 OD Internal strain monitoring in composite materials with embedded photonic crystal fiber Bragg gratings (Invited Paper) [9226-12]

9226 OE Fiber optical sensors for aircraft applications (Invited Paper) [9226-13]

9226 OF Synopsis of fiber optics in harsh environments (Invited Paper) [9226-14]

\section{SESSION 5 ADVANCES IN LASERS, NANOMATERIALS, AND INTEGRATED SYSTEMS}

9226 OG On life assessment of high reliability high power optical switch [9226-15]

$9226 \mathrm{OH}$ Compact VCSEL-based laser array communications systems for improved data performance in satellites (Invited Paper) [9226-16]

9226 Ol Germanium devices for integrated photonic circuits (Invited Paper) [9226-17]

9226 0J Shockwave consolidation of nanostructured thermoelectric materials (Invited Paper) [9226-18]

\section{SESSION 6 ADVANCES IN SPACE POWER TECHNOLOGY}

$9226 \mathrm{OL}$ AIGaAsSb as a top cell material for InP-based triple-junction solar cells (Invited Paper) [9226-20]

9226 OM Engineering polymer frontier orbitals for efficient photon harvesting (Invited Paper) [9226-21]

\section{SESSION 7 ADVANCES IN DETECTOR TECHNOLOGIES I}

9226 OP Mid and long wavelength infrared HgCdTe photodetectors exposed to proton radiation (Invited Paper) [9226-23]

$92260 Q \quad H i g h$ operating temperature midwave infrared (MWIR) photodetectors based on type II InAs/GaSb strained layer superlattice [9226-24]

\section{SESSION $8 \quad$ ADVANCES IN DETECTOR TECHNOLOGIES II}

9226 OR Effect of defects on III-V MWIR nBn detector performance [9226-25]

9226 OS In-situ minority carrier recombination lifetime measurements at radiation sources for rad-hard IR detector materials [9226-26]

9226 OT Biopolymers suitable for space environments (Invited Paper) [9226-27] 


\section{Authors}

Numbers in the index correspond to the last two digits of the six-digit citation identifier (CID) article numbering system used in Proceedings of SPIE. The first four digits reflect the volume number. Base 36 numbering is employed for the last two digits and indicates the order of articles within the volume. Numbers start with 00, 01, 02, 03, 04, 05, 06, 07, 08, 09, OA, OB...0Z, followed by 10-1Z, 20-2Z, etc.

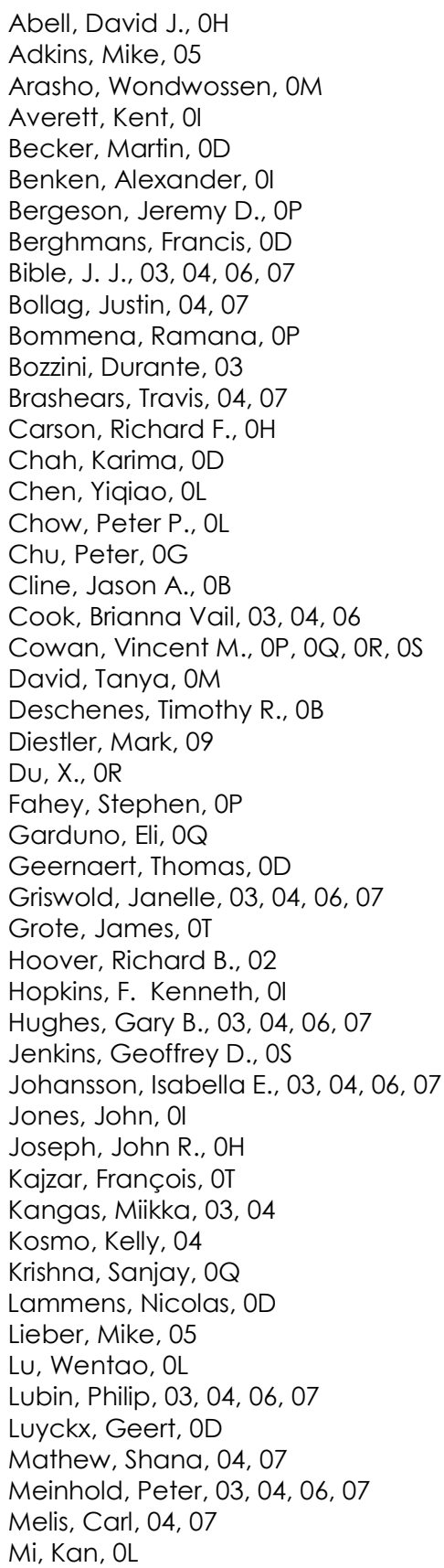

Morath, Christian P., OP, OQ, OR, OS

Motta, Caio, 04

Moy, Aaron, OL

Myers, Stephen, $0 Q$

Nemir, David C., OJ

O'Neill, Hugh, 03, 04, 06, 07

Otis, Kirk J., $\mathrm{OH}$

Ouchen, Fahima, OT

Pechstedt, Ralf D., OE

Perez-Moreno, Javier, OC

Pierce, Robert, 05

Pirich, Ronald, OF

Plis, Elena A., $0 Q$

Prasad, Narasimha S., 09, 0J

Pryor, Jonathan E., OA

Pryor, Mark, 03, 04

Quenneville, Jason, OB

Ramirez, David A., $0 Q$

Rau, lleana, OT

Riley, Jordan, 03, 04, 06, 07

Rosemeier, Jolanta, 09

Savich, G. R., OR

Sidor, D. E., OR

Sonnenfeld, Camille, OD

Suen, Jonathan, 03, 04, 06, 07

Sulejmani, Sanne, OD

Sun, Sam-Shajing, OM

Taylor, Patrick, OJ

Taylor, Ramona S., OB

Thienpont, Hugo, OD

Thiry, Nicolas, 08

Treider, Laura A., OQ

Trivedi, Sudhir, 09

Tsareva, Tatiana, 07

Vasile, Massimiliano, 08

Velicu, Silviu, OP

Voet, Eli, OD

Wallace, Cynthia, 05

Walsh, Kevin M., 01

Walsh, Kevin, 04, 07

Warden, Robert, 05

Warren, Mial E., $\mathrm{OH}$

Watson, Michael D., OA

Weimer, Carl, 05

Wicks, G. W., OR

Wilcox, Thomas, $\mathrm{OH}$

$\mathrm{XU}$, Yuanjian, OG

Yaney, Perry, OT

Zhang, Qicheng, 04, 07 
Proc. of SPIE Vol. $9226922601-6$

Downloaded From: https://www.spiedigitallibrary.org/conference-proceedings-of-spie on 26 Apr 2023 Terms of Use: https://www.spiedigitallibrary.org/terms-of-use 


\section{Conference Committee}

Program Track Chairs

Stephen M. Hammel, Space and Naval Warfare Systems Command (United States)

Alexander M. J. van Eijk, TNO Defence, Security and Safety

(Netherlands)

Conference Chairs

Edward W. Taylor, International Photonics Consultants, Inc.

(United States)

David A. Cardimona, Air Force Research Laboratory (United States)

Conference Co-chairs

Ronald G. Pirich, Northrop Grumman Aerospace Systems (Retired) (United States)

Narasimha S. Prasad, NASA Langley Research Center (United States)

Conference Program Committee

Joseph C. Boisvert, Spectrolab, Inc. (United States)

Yiqiao Chen, SVT Associates, Inc. (United States)

Koen Clays, Katholieke Universiteit Leuven (Belgium)

Jason Cline, Spectral Sciences, Inc. (United States)

Vincent M. Cowan, Air Force Research Laboratory (United States)

Nathan J. Dawson, Youngstown State University (United States)

Jihong Geng, AdValue Photonics, Inc. (United States)

Michael J. Hayduk, Air Force Research Laboratory (United States)

F. Kenneth Hopkins, Air Force Research Laboratory (United States)

Huan Huang, PolarOnyx, Inc. (United States)

Gary B. Hughes, California Polytechnic State University, San Luis

Obispo (United States)

Kenneth J. Jerkatis, Boeing Directed Energy Systems (United States)

Mark G. Kuzyk, Washington State University (United States)

Serge Oktyabrsky, University at Albany (United States)

Javier Pérez-Moreno, Skidmore College (United States)

Sam-Shajing Sun, Norfolk State University (United States)

Michael D. Watson, NASA Marshall Space Flight Center

(United States) 
Session Chairs

Keynote Session

Edward W. Taylor, International Photonics Consultants, Inc.

(United States)

1 Technology for Planetary Defense

Gary B. Hughes, California Polytechnic State University, San Luis Obispo (United States)

2 Space Experiments, Systems, and Components

Michael D. Watson, NASA Marshall Space Flight Center (United States)

Narasimha S. Prasad, NASA Langley Research Center (United States)

3 Theoretical and Simulated Testing of Advanced Photonic Materials Javier Pérez-Moreno, Skidmore College (United States)

Jason Cline, Spectral Sciences, Inc. (United States)

4 Fiber Optic Technology

Ronald G. Pirich, Northrop Grumman Aerospace Systems

(United States)

5 Advances in Lasers, Nanomaterials, and Integrated Systems

Kenneth J. Jerkatis, Boeing Directed Energy Systems (United States)

F. Kenneth Hopkins, Air Force Research Laboratory (United States)

6 Advances in Space Power Technology

Sam-Shajing Sun, Norfolk State University (United States)

Yiqiao Chen, SVT Associates, Inc. (United States)

$7 \quad$ Advances in Detector Technologies I

Vincent M. Cowan, Air Force Research Laboratory (United States)

8 Advances in Detector Technologies II

Vincent M. Cowan, Air Force Research Laboratory (United States) 


\section{Introduction}

The eighth Nanophotonics and Macrophotonics for Space Environment Conference (NMSE VIII) was very well attended and attracted international authors from various universities, major industries and manufacturers, the United States Department of Defense, NASA and small-business enterprises.

A large number of invited papers were presented, as well as an outstanding keynote presentation by past SPIE President Professor Richard B. Hoover of the University of Buckingham and Athens State University. His presentation dealt with "Microfossils and biomolecules in carbonaceous meteorites: implications to the possibility of life in water-bearing asteroids and comets". This presentation and the excellent extensive session on photonic "Technology for Planetary Defense" attracted much audience attention and discussion and potentially heralded the expansion of future conference topics towards new applications for advancing radiation hardened photonic components, systems and capabilities in harsh space environments.

The diversification of presented paper topics included reported advances in: biopolymer-based photonic materials; next-generation solar cells; efficient photon harvesting; radiation hardening and testing results of various new and emerging photodetectors, vertical cavity surface emitting laser arrays, photonic circuits, acoustical-optical devices, optical switches, fiber optic responses in harsh environments and embedded crystal fiber Bragg gratings for sensing applications in space structures and satellites.

As the requirement for ever increasing the efficiency and radiation hardness of photonic technologies necessary for advancing space applications is sought by DOD entities, commercial communication systems, planetary defense organizations, and as the exploration of our universe continues, we can expect that the scientific community will rise to meeting the challenge. Forums such as this SPIE conference will be pivotal and important in bringing like-minded individuals to the forefront for sharing their research and development achievements for the betterment of mankind.

We look forward to convening the next SPIE NMSE conference dealing with advances in nanophotonic and macrophotonic technologies and expansion of the new photonic topic areas we encountered at the NMSE VIII conference.

The chairs wish to thank the NMSE VIII program committee, co-chairs, session chairs, authors and especially the SPIE staff for their assistance and efforts to making the conference a success.

Edward W. Taylor David A. Cardimona 
Proc. of SPIE Vol. $9226922601-10$

Downloaded From: https://www.spiedigitallibrary.org/conference-proceedings-of-spie on 26 Apr 2023 Terms of Use: https://www.spiedigitallibrary.org/terms-of-use 